\title{
MODEL PREFERENSI KONSUMEN TERHADAP PERBANKAN SYARIAH
}

\author{
Purnamie Titisari ${ }^{1}$, Arnis Budi Susanto ${ }^{2 *}$ \\ 1,2 Jurusan Manajemen, Fakultas Ekonomi dan Bisnis, Universitas Jember \\ arnis.feb@unej.ac.id
}

\begin{abstract}
This study aims to build a model of consumer preference in choosing Islamic banking. This study uses a comparative study between people's understanding of Islamic banking and conventional banking which is influenced by several factors. The sample in this study amounted to 200 people who had different backgrounds. Existing data were analyzed using Structural equation models (SEM). The research results show that there is a level of understanding and preference of the community towards different Islamic banking which is influenced by several factors developed in this research model. In the next research, it is expected to conduct an assessment of the decision to choose Islamic and conventional banking products that concentrate more on specific products in Islamic banking. In addition, further research is expected to take into account environmental factors and government policies as well as other factors that have not been studied in this study so that it is expected to enrich the knowledge in the field of management, especially consumer preferences and decision making using Islamic banking products
\end{abstract}

Keyword: Islamic Banking, Consumer Preferences, Decission

\begin{abstract}
ABSTRAK
Penelitian ini bertujuan untuk membangun model preferensi konsumen dalam memilih perbankan syariah. Penelitian ini menggunakan kajian perbandingan antara pemahaman masyarakat mengenai perbankan syariah dan perbankan konvensional yang dipengaruhi oleh beberapa faktor. Sampel dalam penelitian ini berjumlah 200 orang masyarakat yang memiliki latar belakang berbeda. Data yang ada dianalisis dengan menggunakan Structural equation models (SEM) . Hasil penelitan menunjukkan bahwa terdapat tingkat pemahaman dan preferansi masyarakat terhadap perbankan syariah berbeda-beda yang dipengaruhi oleh beberapa faktor yang dikembangkan dalam model penelitian ini. Pada penelitian selanjunya diharapkan melakukan pengkajian mengenai keputusan pemilihan produk perbankan syariah dan konvensional yang lebih berkonsentrasi pada produk yang lebih spesifik di perbankan syariah. Selain itu, penelitian selanjutnya diharapkan mempertimbangkan faktor lingkungan dan kebijakan pemerintah serta faktor lain yang belum diteliti dalam penelitian ini sehingga diharapkan mampu memperkaya khasanah ilmu dalam bidang manajemen khususnya preferensi konsumen dan pengambilan keputusan menggunakan produk perbankan syariah.
\end{abstract}

Kata Kunci: Perbankan Syariah, preferensi konsumen, Keputusan Konsumen 


\section{PENDAHULUAN}

Perbankan syariah merupakan alternatif perbankan yang menerapkan konsep islam dimana perbankan syariah di dalam produknya menggunakan sistem kerja yang berbeda dengan bank konvensional yakni dasar pembagian keuntungan bukan berdasarkan bunga yang dikenakan kepada nasabah, namun menggunakan sistem bagi hasil atau lebih dikenal dengan konsep mudharabah. Keuntungan atau nisbah yang diperoleh harus dibagi oleh kedua belah pihak dan proporsi keuntungan harus dijelaskan saat awal akad dan besarannya berdasarkan proporsi keuntungan yang diperoleh.

Antonio (1999) menjelaskan berbagai tantangan yang dihadapi oleh perbankan syariah. Beberapa permasalahan yang sering dihadapi yaitu masyarakat memiliki pemahaman yang rendah terhadap perbankan syariah disebabkan oleh masih banyaknya perbankan yang didominasi oleh perbankan konvensional. Selain itu jumlah perbankan syariah di Indonesia dinilai masih kurang dibandingkan jumlah perbankan konvensional sehingga masyarakat mengalami kesulitan untuk bertransaksi atau menggunakan perbankan syariah. Hal ini yang menyebabkan masih rendahnya pemahaman masyarakat terhadap perbankan syariah.

Berangkat dari latar belakang tersebut, maka penelitian ini memfokuskan pada kajian literasi dan preferensi masyarakt terhadap perbankan syariah. Penelitian ini bertujuan untuk mengetaui literasi dan preferensi masyarakat mengenai perbankan syariah. Selain itu penelitian ini juga bertujuan untuk menjelaskan faktor yang mempengaruhi literasu dan preferensi masyarakat dalam memilih perbankan syariah.

Penelitian ini diharapkan juga mampu memberikan manfaat baik secara teoritis yaitu diharapan dapat menguji, mengkonfirmasi serta melengkapi kajian teori perilaku konsumen dalam mengambil keputusan (Engel, et.al. 1994), faktor individu (kotler, 2002), (mowen and Minor, 1998), faktos sosial budaya (Engel, 1994). Selain memberikan manfaat secara teoritis.

Berdasarkan pokok pikiran tersebut maka diperlukan penelitian lebih lanjut terkait model preferensi masyarakat terhadap perbankan syariah. Selain secara teoritis, penelitian ini juga diharapkan mampu memberikan manfaat praktis berupa memberikan informasi bagi perilaku konsumen dalam emngambil keputusan menggunakan perbankan syariah, sehingga mampu dijadikan dasar atau pertimbangan manajemen dalam mengembangkan strategi maupun mengoptimalkan sumebrdaya yang dimiliki dalam perbankan syariah.

Ruang lingkup penelitian ini menguji dan memverifikasi beberapa faktor yang mempengaruhi pengambilan keputusan konsumen dalam pengambilan keputusan menggunakan produk perbankan syariah di Jember. 


\section{MASALAH PENELITIAN}

Dari latar belakang di atas maka dapat dirumuskan masalah dalam penelitian ini adalah:

1. Apakah individu akan mempengaruhi preferensi konsumen memilih perbankan Syariah

2. Apakah pemasaran akan mempengaruhi preferensi dalam memilih perbankan Syariah

3. Apakah sosial budaya akan mempengaruhi preferensi konsumen dalam memilih perbankan Syariah.

4. Apakah preferensi konsumen akan mempengaruhi keputusan konsumen memilih perbankan Syariah

\section{KAJIAN TEORITIS}

\section{Perkembangan Perbankan Syariah}

Secara Internasional, Indonesia berada dipandang sebagai kekuatan dan memiliki potensi besar keuangan syariah global dimana Indonesia berada pada urutan negara ke -9 . (World Islamic Banking Competitiveness report, 2014-2015). Indonesia telah memperoleh pengakuan Internasional yakni berada pada posisi to offer lessons bersama negara UAE, Arab Saudi, Malaysia, dan Bahrain, untuk pengembangan keuangan syariah kepada negara lain. Selain itu, Indonesia juga dianggap sebagai kekuatan pendorong keuangan Syariah di masa depan.

Di Indonesia sendiri, walaupun mengalami perkembangan, perbankan syariah mengalami perlambatan pertumbuhan. Hal ini yang menjadi perhatian bagi perbankan syraiah di Indonesia. Adapun penyebab perlambatan pertumbuhan tersebut dijabarkan dalam beberapa isu strategis (Departemen Perbankan Syariah, 2016). Pertama, kurangnya koordinasi pemerintah dan keselarasan visi dan otortias dalam pengembangan perbankan syariah. Kedua, modal yang belum memadai dimana skala industri dan individual bank yang masih kecil serta memiliki tingkat efisiensi yang rendah. Ketiga, biaya dana yang mahal sehingga berdampak pada keterbatasan segmen pembiayaan. Keempat, produk yang dinilai masih kurang variatif dan pelayanan yang belum sesuai dnegan harapan masyarakat, kelima, kuantitas dan kualitas SDM yang belum memadai serta teknologi informasi yang belum dapat mendukung produk dan layanan perbankan syariah. Keenam, rendahnya pemahaman dan kesadaran masyarakat terhadap perbankan syariah. Ketujuh, pengaturan dan pengawasan yang masih belum optimal.

\section{Keputusan Konsumen}

Konsumen memilih menggunakan suatu produk atau jasa akan dipengaruhi oleh berbagai faktor baik faktor eksternal yang berasal dari lingkungan maupun faktor individu itu sendiri (Assael,1998). Sejalan dengan Assael, penelitian yang menyatakan hal serupa juga dikemukakan oleh Koklic dan Vida (2009), dimana di dalam penelitiannya mengemukakan bahwa konsumen mengambil keputusan memiliki dorongan baik yang berasal dari internal individu maupun ekternal. Terkait dengan penelitian ini, kedua penelitian tersebut menjelaskan bagaimana konsumen dalam 
memilih perbankan juga memiliki dorongan atau motivasi baik yang berasal dari dalam individu maupun eksternal individu tersebut.

Proses pengambilan keputusan pembelian merupakan proses pembelian yang dilalui oleh seorang konsumen akhir yang dimulai dari timbulnya rasa butuh sampai kepada perasaannya setelah melakukan pembelian. Kotler (2002). Lovelock \& Wright (2002) menyatakan bahwa pembuatan keputusan konsumen merupakan suatu proses pengambilan keputusan konsumen terhadap produk atau layanan yang terdiri dari 3 tahap, yaitu: (1) tahap sebelum pembelian, (2) tahap pembelian, dan (3) tahap kegiatan pasca pembelian.

Menurut Schiffman (2007) pada tahap sebelum pembelian, konsumen akan melakukan hal-hal sebagai berikut, yaitu (1) pengenalan kebutuhan, (2) pencarian informasi, (3) alternatif evaluasi. Pengenalan kebutuhan didefinisikan sebagai persepsi atas perbedaan antara keadaan yang diinginkan dengan situasi aktual yang memadai untuk menggugah dan mengaktifkan proses pembelian, Schiffman (2007), Engel, Blackwell dan Miniard (1995)

$$
\text { Menurut Peter dan Olson (2000), }
$$
pembuatan keputusan konsumen merupakan suatu aliran interaksi (stream interaction) antara proses faktor lingkungan, kognitif, dan apektif serta tindakan perilaku. Terdapat lima tahapan dasar atau sub-proses dalam pengambilan keputusan konsumen, antara lain : 1) Pengenalan masalah, 2) mencari alternatif pemecahan, 3) mengevaluasi alternatif dan memilih, 4) melakukan pembelian, 5) menggunakan produk yang dibelinya dan melakukan evaluasi ulang.

\section{Individu}

Keputusan pembelian akan dipengaruhi oleh faktor yang berasal dari dalam individu itu sendiri (Schiffman, 2007). Dalam konteks hubungan individu ini, setiap individu atau konsumen memiliki mental yang akan dipengaruhi oleh stimuli yang bersifat afektif dan kognitif yang ada disekitarnya (Peter dan Olson, 2000). Lebih lanjut, Solomon (2002) menjelaskan secara mendetail mengenai faktor individu lebih merujuk kepada sifat atau ciri khusus individu merespon lingkungan sekitarnya. Faktor individu ini secara spesifik dapat dijabarkan menjadi jenis pekerjaan, dan gaya hidup serta tingkat pendapatan. (Jhingan, 2000).

Gaya hidup merupakan karakteristik yang mempengaruhi preferensi konsumen dalam menentukan pengambilan keputusan pembelian. Gaya hidup pribadi yang dimaksud adalah gaya hidup modern yang selalu mengikuti trend perkembangan modifikasi produk, dibandingkan dengan gaya hidup pribadi konsumen yang sederhana, yang cenderung mengikuti perkembangan modifikasi yang sederhana pula sesuai dengan pembawaan dan minat pribadi masing-masing konsumen.

Jhingan (2000:133) menjelaskan adanya suatu lilitan lingkaran yang sangat mempengaruhi karakteristik kepribadian dari konsumen untuk mengembangkan perilakunya dalam mengambil suatu keputusan. Karakteristik pribadi dari setiap individu tidak terlepas dari adanya perbedaan atas jenis pekerjaan yang dimiliki sesuai dengan jenis 
usaha yang ditekuninya. Terjadinya perbedaan jenis pendapatan menurut pekerjaan akan memberikan gaya hidup dari konsumen yang berbeda-beda dalam pengambilan keputusan pembelian. Terlihat dari konsumen yang memiliki pendapatan tinggi berbeda dengan konsumen yang memiliki pendapatan rendah, sehingga gaya hidup mempunyai keterkaitan mempengaruhi kepribadian.

Schiffman, (2007) menyatakan bahwa kepribadian adalah bentuk identitas yang dimiliki oleh setiap konsumen dalam menentukan perilakunya untuk mengambil suatu keputusan pembelian yang tepat atau penjualan yang tepat sesuai dengan pertimbangan rasional dan emosional yang dipahaminya. Secara eksplisit menjelaskan pribadi individu yang mempengaruhi preferensi konsumen yakni berupa jenis pekerjaan dan gaya hidup. Pekerjaan konsumen juga sangat ditentukan dalam perilakunya mengambil keputusan pembelian. Konsumen yang berpendapatan tinggi cenderung membeli produk yang agak mahal dibandingkan dengan konsumen yang berpendapatan menengah atau rendah.

Demikian pula dengan gaya hidup merupakan karakteristik yang mempengaruhi preferensi konsumen dalam menentukan pengambilan keputusan pembelian. Gaya hidup pribadi yang dimaksud adalah gaya hidup modern yang selalu mengikuti trend perkembangan modifikasi produk, dibandingkan dengan gaya hidup pribadi konsumen yang sederhana, yang cenderung mengikuti perkembangan modifikasi yang sederhana pula sesuai dengan pembawaan dan minat pribadi masing-masing konsumen.

\section{Pemasaran}

Selain faktor individu, preferensi masyarakat dalam memilih suatu produk dan juga memahami mengenai suatu produk dapat dipengaruhi oleh faktor pemasaran. Pemasaran berguna untuk mengenalkan suatu produk kepada masyarakat dan bertujuan untuk menyampaikan pesan dan makna layanan serta mengendalikan pasar sasaran (kotler,2002).

Pemasaran adalah suatu proses sosial yang didalamnya individu atau kelompok mendapatkan apa yang mereka butuhkan dan inginkan dengan menciptakan, menawarkan, dan secara bebas mempertukarkan produk yang bernilai dengan pihak lain (Kotler, 2002). Menurut American Marketing Association dalam Kotler (2002) mendefinisikan pemasaran sebagai suatu proses perencanaan dan eksekusi, mulai dari tahap konsepsi, penetapan harga, promosi, hingga distribusi barang-barang, ideide, jasa-jasa, untuk melakukan pertukaran yang memuaskan individu dan lembaga-lembaganya.

Menurut Boyd, Walker dan Larecce (2000) pemasaran sebagai suatu proses sosial yang melibatkan kegiatan-kegiatan penting yang memungkinkan individu dan perusahaan mendapatkan apa yang mereka butuhkan dan inginkan melalui pertukaran dengan pihak lain dan untuk mengembangkan hubungan pertukaran.

Fokus dalam aspek pemasaran yaitu bagaimana mengkoordinasikan sumberdaya yang dimiliki dan merancang aktivitas pemasaran yang efektif. Stimulus pemasaran 
merupakan aspek strategi perusahaan yang penting bagi perusahaan. Konsumen dalam mengambil keputusan juga dapat melihat stimulus pemasaran yang juga berdampak pada preferensi konsumen. Semakin paham perusahaan akan stimulus pemasaran maka memudahkan perusahaan dalam mengelola keputusan konsumen. Best (2000) menegaskan bahwa strategi pemasaran atau aspek pemasaran yang tepat secara langsung akan mempengaruhi preferensi konsumen dan keputusan pembelian konsumen.

Komunikasi atau rangsangan lainnya terdiri dari kekuatan-kekuatan dan kejadiankejadian penting dalam lingkungan pembeli: lingkungan ekonomi, teknologi, politik dan budaya. Semua rangsangan ini akan melewati kotak hitam pembeli dan menghasilkan serangkaian tanggapan dari para pembeli yang bisa diteliti, sehinga pemasar perlu memahami apa yang terjadi dengan kotak hitam antara rangsangan dan tanggapan. Bagi menurut masyarakat umum, pemasaran hanya merupakan penjualan dan periklanan seperti melalui surat kabar, televisi, selebaran dan lain sebagainya. Secara definitif menurut Kotler konsep pemasaran adalah kunci untuk mencapai tujuan organisasi yang terletak pada penentuan kebutuhan dan keinginan dari pada pasar sasaran dan pada pemberian kepuasan yang diinginkan dengan lebih efektif dan efisien dari pada para pesaing.

$$
\text { Blackwell, miniard }
$$
mengemukakan konsep yang menjelaskan bagaimana keterkaitan keputusan konsumen dengan aspek pemasaran. Dalam model yang dikembangkannya, seorang individu atau konsumen dalam mengambil keputusan dikaitkan dengan bagaimana individu tersebut memperoleh informasi yang kemudian menjadi ingatan bagi konsumen tersebut sebelum melakukan pembelian atau pengambilan keputusan. Dalam membangun ingatan tersbeut ada beberapa anteseden yang dapat membentuknya yaitu aspek pemasaran yang akan membentuk preferensi mkonsumen dalam mengambil keputusan.

\section{Sosial Budaya}

Salah satu dimensi yang mengukur keputusan konsumen dan preferensi konsumen yaitu aspek sosial budaya. Berbagai riset telah menjelaskan bagaimana keterkaitan aspek sosial budaya ini terhadap bagaimana masyarakat atau konsumen dalam sikap pengambilan keputusan mereka karena memperngaruhi sikap dan perilaku mereka. Engel (1994) menjelaskans etidaknya ada ebberapa hal yang menekankan pentingnya pengaruh sosial budaya terhadap perilaku konsumen yaitu dengan mempelajari aspek sosial budaya maka dapat mengetahui bagaimana struktur ekonomi konsumen, kedua, budaya juga dapat mempengaruhi konsumen dalam emngambil keputusan. Ketiga, budaya dapat mengkomunikasikan makna dalam suatu produk.

Karakteristik sosial budaya umumnya merupakan pengertian yang lebih bersifat implementasi mengenai pemahaman konsumen terkait preferensi mereka dan pengambilan keputusan konsumen yang sesuai dengan karakteristik budaya sehingga akan 
mengarahkan konsumen tersebut membuat pola atau bentuk model produk yang akan mereka gunakan sesuai dengan karakteristik sosial dan budaya mereka.

Secara tegas juga dikemukakan bahwa untuk mengembangkan karakteristik budaya yang dimiliki oleh seorang konsumen dalam menentukan keputusan pembelian, pada dasarnya konsumen mempertanyakan aspekaspek penilaian budaya yang mencakup penilaian makna bentuk fisik dan model yang bernilai artistik dari tinjauan budaya yang menjadi pertimbangan dalam pengambilan keputusan pembelian berdasarkan perilaku yang dimilikinya.

Faktor sosial budaya merupakan faktor eksternal yang mempengaruhi pemahaman dan preferensi konsumen hingga pengambilan keputusan konsumen terhadap suatu produk atau jasa. Sosial budaya merupakan pola yang ebrsifat kultural yang ada dan berlaku di masyarakat (Macionis, 1996). Karakteristik sosial budaya pada dasarnya merupakan pengertian yang menekankan penerapan litrasi mengenai preferensi konsumen dalam pengambilan keputusan sesuai dengan karakteristik budaya yang mengarahkan konsumen produk atau jasa yang sesuai dengan karakteristik budaya masing-masing konsumen.

De Silva et al. (2010) menjelaskan bahwa jenis kepercayaan dan budaya yang dimiliki oleh seseorang akan memiliki dampak terhadap kecenderungan perilaku seseorang. Dengan demikian suatu organisasi sebaiknya memahami nilai-nilai sosial budaya dalam membuat keputusan dalam memahami preferensi konsumen dan seberapa baik organisasi tersebut menggabungkan pemahaman tersebut kedalam rencana strategi organisasi tersebut (Leo et al., 2005).

Secara hirarki, individu konsumen cenderung mempertanyakan nilai dari suatu obyek bentuk fisik produk yang ingin dibeli. Apakah mempunyai nilai historis, prestise, keunikan dan lain sebagainya. Sikap konsumen memahami obyek bentuk fisik yang diinginkan sangat ditentukan oleh substansi dan eksistensi obyek yang ingin dibeli, sedangkan prinsip dari obyek yang ingin dibeli pada dasarnya mengacu kepada adanya manfaat dan keuntungan yang ingin dicapai.

Demikian pula dengan model artistik atas produk yang menjadi tujuan suatu pembelian, selalu bertumpu kepada pertimbangan apakah termasuk model bernilai artistik tinggi, baru dan temporer terhadap produk yang ingin dibeli.

Uraian di atas secara konsisten menunjukkan bahwa karakteristik sosial budaya yang mencakup bentuk dan model suatu produk mempengaruhi preferensi konsumen, memainkan peranan yang sangat penting sesuai dengan substansi dan pemaknaan yang dimiliki dari masing-masing pemahaman karakteristik budaya konsumen.

\section{Preferensi Konsumen}

Preferensi konsumen di dalam penelitian ini dimaksudkan menjelaskan bagaimana keenderungan masyarakat dalam perbankan syariah. Preferensi konsumen akan berkaitan erat dengan bagaimana penilaian yang dilakukan konsumen, sehingga menunjukkan rasa puas atau tidak. Hal ini sejalan dnegan pendapat yang dikemukakan oleh Tjiptono 
(2008) dimana dalam pendapatnya menjelskan bahwa kepuasan atau ketidak puasan masyarakat atau konsumen terhadap produk atau jasa yang ditawarkan akan mempengaruhi pengambilan keputusan konsumen tersebut. Preferensi akan menunjukkan tingkat kesukaan atau kecenderungan masyarakat atau konsumen dalam memilih suatu produk atau jasa yang ditawarkan. Preferensi ini juga akan dipengaruhi berbagai faktor seperti faktor internal dan eksternal dari konsumen.

Preferensi konsumen merupakan sikap konsumen yang menginginkan suatu barang atau jasa berdasarkan ekmampuan yang mereka miliki Dengan kata lain, preferensi konsumend apat dikatakan sebagai interaksi dinamis antara perilaku dan kejadian yang akan mempengaruhi kecenderungan mereka dalam emmilih barang atau jasa tertentu. Dengan demikian dapat disimpulkan bahwa preferensi konsumen lebih ebrsifat sesuatu yang dinamis yang didalamnya terdiri dari pelibatan atau pertukaran informasi sehingga memperkuat kecenderungan konsumen dalam memilih sesuatu.

Menurut Kotler (2002) peranan preferensi konsumen adalah pemrakarsa (initiator), pemberi pengaruh (influencer), pengambilan keputusan (decider), pembeli (purchaser) dan pengguna/pemakai (user). Pemrakarsa adalah individu yang mempunyai inisiatif pembelian tertentu atau yang mempunyai kebutuhan/keinginan, tetapi tidak mempunyai wewenang untuk melakukannya sendiri. Pemberi pengaruh adalah individu yang mempengaruhi keputusan untuk membeli, baik secara sengaja atau tidak sengaja. Pengambil keputusan (decider) adalah individu yang akan memutuskan apakah akan membeli atau tidak, apa yang akan dibeli, bagaimana membelinya, kapan dan dimana. Pembeli adalah orang yang benar-benar melakukan pembelian. Dan pengguna/ pemakai adalah individu yang menggunakan produk atau jasa yang dibeli.

Dengan memahami preferensi konsumen, perusahaan akan memberikan kepuasan kepada pelanggan. Model Kano dalam kepuasan konsumen menjadi model yang relevan untuk memahami secara mendalam tentang preferensi konsumen dengan menganalisis dan mengkaji atribut produk yang ditawarkan pemasar (Gruber, et al. 2008). Mempelajari preferensi konsumen sangat kompleks, yang dikarenakan banyaknya karakteristik yang mempengaruhi dan kecenderungan untuk saling berinteraksi. Howard dan Sheth (1998:68) mengemukakan preferensi konsumen dalam suatu gambaran proses pengambilan keputusan membeli. Preferensi konsumen terdiri atas empat komponen pokok yakni masukan (stimuli), susunan hipotesis (susunan persepsi melalui proses belajar), hasil tanggapan atau keputusan membeli dan karakteristik-karakteristik eksogen.

\section{METODOLOGI}

Penelitian ini menggunakan pendekatan kuantitatif. Jenis data yang digunakan yakni data primer dan sekunder. Data primer dilakukan dengan melalui wawancara dan kuesioner, sedangkan data sekunder diperoleh dari berbagai sumber yang relevan. Pengambilan sampel penelitian dilakukan di 
Jember dengan pertimbangan potensi penduduk mayoritas agama (Islam) dan memiliki budaya yang masih melekat dengan keagamaan serta memiliki potensi faktor ekonomi. Sampel yang digunakan dalam penelitian ini sebanyak 200 responden yang berasal dari beberapa latar belakang yang berbeda. Pengambilan responden dilakukan dengan menggunakan teknik accidental sampling. Untuk menguji masingmasing variabel dalam penelitian ini dilakukan uji validitas dan reliabilitas. Kemudian data yang ada diolah dengan menggunakan structural equation models (SEM) dengan menggunakan program AMOS.

\section{PEMBAHASAN}

Di dalam penelitian ini menggunakan 3 (tiga) variabel exogenous dan 2 (dua) variabel endogenous. Sebelum melakukan pengujian model penelitian maka dilakukan pengujian Confirmatory Factor Analysis (CFA). Adapun hasil CFA dapat dilihat pada tabel berikut:

Tabel 1

\section{Hasil Goodness of Fit Variabel Penelitian}

\begin{tabular}{|c|c|c|c|c|c|c|}
\hline $\begin{array}{l}\text { Goodnes } \\
\text { Of Fit } \\
\text { Indices }\end{array}$ & $\begin{array}{c}\text { Cut } \\
\text { Off } \\
\text { Value }\end{array}$ & Pribadi & $\begin{array}{l}\text { Pema- } \\
\text { saran }\end{array}$ & $\begin{array}{c}\text { Nilai } \\
\text { Sosial } \\
\text { dan } \\
\text { Budaya }\end{array}$ & $\begin{array}{c}\text { Prefe- } \\
\text { rensi } \\
\text { Kon- } \\
\text { sumen }\end{array}$ & $\begin{array}{r}\text { Kepu } \\
\text { tusar } \\
\text { Konsı } \\
\text { men }\end{array}$ \\
\hline $\begin{array}{l}\mathrm{X}^{2} \mathrm{Chi} \\
\text { Square }\end{array}$ & $\begin{array}{l}\text { Diharap- } \\
\text { kan kecil }\end{array}$ & 0,00 & 3,607 & 0,00 & 1,501 & 1,30 \\
\hline Probabilitas & $\geq 0,05$ & 0,367 & 0,165 & 0,57 & 0,472 & 0,06 \\
\hline $\mathrm{CMIN} / \mathrm{DF}$ & $\leq 2,00$ & 1,120 & 1,447 & 1,247 & 1,298 & 2,861 \\
\hline GFI & $\geq 0,90$ & 0,984 & 0,953 & 0,978 & 0,994 & 0,94 \\
\hline AGFI & $\geq 0,90$ & 0,967 & 0,992 & 0,981 & 0,971 & $0,94:$ \\
\hline TLI & $\geq 0,95$ & 0,984 & 0,965 & 0,958 & 0,964 & 0,95 \\
\hline CFI & $\geq 0,95$ & 0,995 & 0,972 & 0,953 & 0,985 & 0,951 \\
\hline RMSEA & $\leq 0,08$ & 0,018 & 0,009 & 0,121 & 0,017 & 0,04 \\
\hline
\end{tabular}

Berdasarkan hasil pengujian CFA pada

tabel 1 menunjukkan bahwa semua kriteria telah terpenuhi. Dengan demikian dapat dikatakan bahwa variabel-variabel yang digunakan dalam penelitian in sudah fit atau sesuai dan memenuhi kriteria.

\section{Pengujian Hipotesis Penelitian}

Berdasarkan model penelitian yang dikembangkan dalam penelitian ini, maka kita melakukan pengujian hipotesis dengan menggunakan koefisien pengaruh di dalam model persamaan struktural (SEM). Adapun hasil pengujian dapat dilihat pada tabel berikut:

Tabel 2

Pengujian Hipotesis

\begin{tabular}{|c|c|c|c|c|c|c|c|c|c|}
\hline \multirow[b]{2}{*}{ HIP } & \multirow{2}{*}{\multicolumn{2}{|c|}{$\begin{array}{l}\text { Variabel } \\
\text { Exogenous }\end{array}$}} & \multirow{2}{*}{\multicolumn{2}{|c|}{$\begin{array}{c}\text { Variabel } \\
\text { Endogenous }\end{array}$}} & \multicolumn{5}{|c|}{ Pengaruh Langsung } \\
\hline & & & & & \multicolumn{2}{|c|}{ Standardize } & CR & p-value & Keterang \\
\hline H1 & \multicolumn{2}{|c|}{ Individu } & \multicolumn{2}{|c|}{$\begin{array}{c}\text { Preferensi } \\
\text { Konsumen }\end{array}$} & \multicolumn{2}{|l|}{0,302} & 2,810 & 0,032 & Significan \\
\hline $\mathrm{H} 2$ & \multicolumn{2}{|c|}{ Pemasaran } & \multicolumn{2}{|c|}{$\begin{array}{c}\text { Preferensi } \\
\text { Konsumen }\end{array}$} & \multicolumn{2}{|l|}{0,420} & 2,342 & 0,027 & Significan \\
\hline $\mathrm{H} 3$ & \multicolumn{2}{|c|}{$\begin{array}{c}\text { Nilai Sosial } \\
\text { Budaya }\end{array}$} & \multicolumn{2}{|c|}{$\begin{array}{c}\text { Preferensi } \\
\text { Konsumen }\end{array}$} & \multicolumn{2}{|l|}{0,266} & 2,4 & 0,015 & Signific \\
\hline $\mathrm{H} 4$ & \multicolumn{2}{|c|}{$\begin{array}{c}\text { Preferensi } \\
\text { Konsumen }\end{array}$} & \multicolumn{2}{|c|}{$\begin{array}{l}\text { Keputusan } \\
\text { Konsumen }\end{array}$} & \multicolumn{2}{|l|}{0,408} & 2,391 & 0,003 & Significan \\
\hline \multicolumn{10}{|c|}{ Pengaruh Tidak Langsu } \\
\hline \multicolumn{2}{|c|}{\begin{tabular}{|l|} 
Variabel \\
Exogenous
\end{tabular}} & \multicolumn{2}{|c|}{\begin{tabular}{|l|} 
Variabel \\
Endogenous \\
\end{tabular}} & \multicolumn{2}{|c|}{\begin{tabular}{|l|} 
Variabel \\
Intervening \\
\end{tabular}} & \multicolumn{2}{|c|}{ Standardize } & \multicolumn{2}{|c|}{ Keterangan } \\
\hline \multicolumn{2}{|c|}{$\begin{array}{l}\text { H1. } \\
\text { Individu }\end{array}$} & \multicolumn{2}{|c|}{\begin{tabular}{|l|} 
Keputusan \\
Konsumen
\end{tabular}} & \multicolumn{2}{|c|}{$\begin{array}{l}\text { Preferensi } \\
\text { Konsumen }\end{array}$} & & 0, & \multicolumn{2}{|c|}{ Significant } \\
\hline \multicolumn{2}{|c|}{$\begin{array}{l}\mathrm{H} 2 . \\
\text { Pemasaran }\end{array}$} & \multicolumn{2}{|c|}{$\begin{array}{l}\text { Keputusan } \\
\text { Konsumen }\end{array}$} & \multicolumn{2}{|c|}{$\begin{array}{l}\text { Preferensi } \\
\text { Konsumen }\end{array}$} & & 0,324 & \multicolumn{2}{|c|}{ Significan } \\
\hline \multicolumn{2}{|c|}{$\begin{array}{l}\text { H3. Nilai } \\
\text { Sosial } \\
\text { Budaya }\end{array}$} & \multicolumn{2}{|c|}{$\begin{array}{l}\text { Keputusan } \\
\text { Konsumen }\end{array}$} & \multicolumn{2}{|c|}{$\begin{array}{l}\text { Preferensi } \\
\text { Konsumen }\end{array}$} & & 0,361 & Sig & nnificant \\
\hline
\end{tabular}

Sumber: data diolah 2018

Hasil yang diperoleh menunjukkan bahwa hipotesis pertama pada penelitian ini diterima dan memiliki pengaruh yang positif Hasil ini menunjukkan bahwa faktor pengaruh individu memiliki pengaruh terhadap preferensi konsumen. hasil ini juga menjelaskan bahwa faktor individu akan mampu membentuk preferensi konsumen. Kepribadian seseorang merupakan bentuk dari identitas individu akan menentukan perilaku mereka dalam hal ini konsumen untuk mengambil keputusan sesuai dengan pertimbangan emosi atau gaya hidup dan kepribadian yang akan mempengaruh preferensi mereka. 
Hasil penelitian ini sejalan dengan beberapa penelitian terdahulu antara lain yang dilakukan oleh Abiden dan Saleem (2012) dimana dalam penelitiannya mereka menemukan bahwa hubungan positif antara emosi seseorang yang dibentuk dari faktor pribadi individu konsumen merupakan variabel yang memiliki hubungan kuat dengan preferensi dan perilaku pembelian oleh konsumen. .

Hasil penelitian ini membuktikan bahwa aspek pribadi berupa gaya hidup dan keprobadian akan mempengaruhi preferensi masyarakat dalam memilih perbankan. Gaya hidup dipandang mampu mempengaruhi preferensi karena masyarakat memandang bahwa perbankan yang mereka pilih dengan mempertimbangkan bagaimana prospek di masa yang akan datang. Pada perbankan syariah, umumnya nasabah masih berangapan bahwa prospek perbankan syariah di masa yang akan datang belum setara dengan apa yang ditawarkan oleh perbankan konvensional hanya sebagian kecil saja diantara nasabah yang meandang perbankan syariah akan memiliki prospek yang cerah di masa yang akan datang. Selain itu masyarakat juga memandang isu sosial yang ada sebagai faktor yang mempengaruhi preferensi mereka dalam memilih perbankan. Sedangkan untuk kepribadian, sebagian besar masyarakat beranggapan bahwa tidak terlalu berdampak pada preferensi mereka dalam memilih perbankan.

Terkait dengan faktor individu berupa kebutuhan gaya hidup, pandey(2013) mengemukakan dalam penelitiannya bahwa produsen juga harus mempertimbangkan kebutuhan akan gaya hidup. Hal ini didasari oleh konsumen sebagai podasi dari setiap bisnis, sehingga terkadang konsumen memperhatikan gaya hidup sebagai preferensi mereka dalam memilih suatu produk dan melakukan keputusan pembelian.

Faktor individu juga berpengaruh terhadap pengambilan keputusan secara tidak langsung melalui preferensi. Hal ini sejalan juga dengan penelitian yang dilakukan oleh Jhon (2013) dimana dalam penelitiannya menyatakan bahwa individu memiliki kecenderungan harapan yang khas sehingga mempengaruhi mereka dalam preferensi beberapa pilihan sebelum mengambbil keputusan pembelian. Dalam hal produk syariah hal ini dapat dikatakan bahwa konsumen melihat pilihan-pilihan yang ada sebelum melakukan keputusan memilih produkproduk perbankan syariah maupun produk konvensional berdasarkan kecenderunagn mereka yang khas dari faktor individu mereka. Para konsumen dalam berpikir dan berperilaku lebih mudah untuk dipahami jika mereka memiliki kekhususan dari faktor individu yang menentukan preferensi mereka yang akan berdampak pada perilaku pengambilan keputusan mereka.

\section{Pengaruh Aspek Pemasaran terhadap Preferensi Konsumen dan Keputusan \\ Konsumen}

Castro (2006) dalam penelitiannya menjelaskan bagaimana keterkaitan antara pemasaran dan perilaku konsumen. Lebih lanjut penelitian tersebut menjelaskan bahwa tidak mungkin 
aspek pemasaran diabaikan oleh konsumen dalam pengambilan keputusan.

Tabel 6, menunjukkan hasil pengujian hipotesis yang menjelaskan bahwa terdapat pengaruh yang positif aspek pemasaran terhadap preferensi konsumen. hasil ini mejelaskan bahwa hipotesis kedua pada penelitian ini diterima. Aspek pemasaran akan mampu mempengaruhui preferensi konsumen dalam mengambil keputusan.

Hasil penelitian membuktikan bahwa aspek pemasaran yang dilakukan perbankan memegang peranan yang cukup penting bagi perbankan baik syariah maupun konvensional. Aspek pemasaran berupa produk yang ditawarkan, lokasi yang terjangkau dan intensitas promosi dalam memberikan informasi kepada masyarakat akan mempengaruhi preferensi konsumen dalam memilih perbankan. Di dalam penelitian ini juga menunjukkan kurangnya informasi atau aspek pemasaran yang dilakukan oleh bank syariah menyebabkan rendahnya literasi masyarakat terkait perbankan syariah. Masyarakat lebih mengenal perbankan konvensional karena memiliki lokasi yang relatif banyak dan mudah dijangkau. Dari aspek produk, kurangnya promosi juga berdampak pada ketidak pahaman masyarakat terhadap produk perbankan syariah sehingga kecenderungan masyarakat lebih memilih perbankan konvensional. Peranan promosi serta saluran promosi juga memegang peranan penting dalam memberikan informasi, perbankan syariah dipandang kurang dalam melakukan promosi baik dari aspek kekhususan, kekhasan dan menariknya promosi yang dilakukan perbankan syariah dibandingkan perbankan konvensional.

Hasil dari penelitian ini sejalan dengan penelitian yang dilakukan oleh Lee, and Liao (2009) dalam penelitiannya yang membahas mengenai aspek pemasaran sebagai penentu perilaku konsumen dalam memilih produk. Pemasaran memegang peranan penting bagi konsumen untuk emngetahui dan memahami produk atau jasa yang ditawarkan oleh produsen. Sehingga konsumen memiliki kecenderungan preferensi untuk memilih produk atau jasa yang mereka kenal dengan baik sebelum melakukan pembelian.

Setelah konsumen memiliki preferensi, maka konsumen tersebut melakukan keputusan pembelian. Hal ini sejalan dengan penelitian yang dilakukan oleh Furaiji (2012). Dalam penelitiannya Furaji menjelaskan bahwa faktor bauran pemasaran akan emmbentuk preferensi konsumen dan berkaitan erat dengan pembelian konsumen. Hasil ini juga menjelaskan bahwa pemasaran memegang peranan penting bagi konsumen dalam membentuk preferensi dan keputusan mereka dalam melakukan pembelian.

Hasil ini sejalan dengan penelitian yang dilakukan oleh Huimin (2013). Dalam penelitiannya menjelaskan keterkaitan antara pentingnya aspek pemasaran etrhadap pengambilan keputusan konsumen. Temuan dari penelitian tersebut menyatakan bahwa iklan dari berbagai onformasi produk yang ditawarkan di media sosial dipengaruhi berbagai jenis pendekatan yang akan mempengaruhi konsumen mengambil keputusan. Sedangkan dalam penelitian ini, aspek pemasaran juga tidak hanya 
emmpengaruhi preferensi konsumen saja namun juga berdampak pada pengambilan keputusan. Setelah konsumen mengetahui berbagai macam informasi yang mereka perlukan terkait produk atau jasa yang ditawarkan, mereka akan memiliki preferensi memilih produk atau jasa sesuai dengan informasi yang mereka sukai sehingga akan menjadi pertimbangan mereka dalam emilih produk perbankan syariah atau konvensional.

Selain itu keterkaitan antara hubungan aspek pemasaran dan keputusan konsumen dapat dijelaskan sebagai Consumer purchasing decision process yang dibagi dalam beberapa tahapan. pertama yang dikenal sebagai need recognition. Kebutuhan berasal dari masalah yang ada atau tertarik oleh beberapa stimulus pemasaran. Tahap kedua adalah pencarian informasi. Dalam tahap ini, pelanggan yang tertarik untuk memecahkan masalah kebutuhan mereka akan memutuskan berapa banyak informasi yang dibutuhkan dengan mencari di sekitar. Tahap berikutnya dalam proses keputusan pembelian konsumen adalah evaluasi alternatif di mana pelanggan mengevaluasi semua informasi yang dikumpulkan pada tahap sebelumnya. Langkah selanjutnya akan membuat keputusan untuk membeli produk (Huimin dan Wei, (2013).

Keterlibatan konsumen adalah tingkat keterlibatan dan pengolahan aktif konsumen melakukan dalam menanggapi stimulus pemasaran. Produk dengan keterlibatan tinggi adalah mereka yang membeli produk bersedia untuk menghabiskan banyak waktu dan usaha dalam mencari merek-nya. Produk keterlibatan rendah sering dan dengan pemikiran minimal dan usaha untuk membeli tidak menjadi perhatian penting dan tidak memiliki dampak yang besar pada gaya hidup konsumen (Rajasekhar dan Makesh, 2011).

\section{Pengaruh Nilai Sosial Budaya terhadap Preferensi Konsumen dan Keputusan Konsumen}

Tabel 7 menunjukkan pengujian hipotesis bahwa hipotesis ketiga pada peelitian ini diterima dan memiliki pengaruh yang positif Hal ini menunjukkan bahwa faktor sosial budaya yang terdiri dari nilai budaya yang ada dimasyarakat, kelompok rujukan, peran keluarga, status sosial mempengaruhi preferensi konsumen dalam mengambil keputusan.

Hasil penelitian ini membuktikan bahwa niai sosial budaya yang ada di masyarakat akan mempengaruhi preferensi konsumen dalam memilih perbankan. Dalam nilai sosial dan busaya ini, masyarakat memperhatikan berbagai aspek seperti budaya yang ada di masyarakat, kelas sosial, kelompok rujukan dan keluarga dalam mengambil keputusan. Sebagain responden memandang bahwa dalam memperhatikan nilai-nilai agama. Hal ini yang menjadi sasaran bagi perbankan syariah untuk mendapatkan nasabah, namun selain aspek agama, masyarakat juga memperhatikan beberapa informasi atau masukan dari kelompok rujukan ataupun keluarga. Di dalam penelitian ini juga menunjukkan bahwa sebagian nasabah perbankan syariah memandang bahwa aspek nilai sosial dan budaya akan mempengaruhi kecenderungan mereka dalam memilih perbankan. 
Penelitian ini relevan dengan penelitian Lawan, dan Zanna, (2013) yang meneliti faktorfaktor sosial budaya yang mempengaruhi perilaku pembelian konsumen pakaian dengan menggunakan analisis statistik deskriptif dan chi square menunjukkan bahwa konsumen pakaian membutuhkan pengakuan yang mana sebagian besar dipengaruhi oleh pendapatan. Komponen asal masukan terdiri dari rangsangan eksternal yang berfungsi sebagai sumber informasi tentang produk tertentu dan mempengaruhi nilai-nilai yang terkait dengan produk konsumen, sikap, dan perilaku dan pengaruh sosial budaya, yang ketika diinternalisasikan dapat mempengaruhi keputusan pembelian konsumen.

Studi Silva et al, (2010) yang menyatakan bahwa agama dan budaya yang terkait dengan kepercayaan memiliki dampak yang kuat pada jenis produk yang dikonsumsi. Dengan demikian, keberhasilan suatu perusahaan dalam market dengan budaya yang berbeda akan dipengaruhi oleh sebagian besar para pembuat keputusan dalam memahami perilaku pembelian konsumen, dan seberapa baik mereka mampu menggabungkan pemahaman tersebut ke dalam rencana dan strategi pemasaran (Leo, et al, 2005).

Studi lain yang dilakukan Mutsikiwa, dan Basera, (2012) yang menganalisis konteks sosial-budaya dalam bisnis dapat berdampak pada persepsi konsumen. Strategi pemasaran interaktif seperti pakaian fashion yang dilakukan Rajagopal, (2011) telah menunjukkan konvergensi nilai-nilai tradisional dan modern dan gaya hidup untuk mengembangkan budaya konsumen global homogen. Dinamika tersebut dalam preferensi konsumen dianggap sebagai bagian dari sistem budaya internasional dan didorong oleh perubahan yang terjadi secara terus-menerus.

Demikian pula penelitian dari Sawant, (2012) yang menemukan bahwa 95\% dari kesadaran adalah karena iklan dan $90 \%$ dari preferensi konsumen adalah karena kesadaran yang diciptakan oleh iklan (Sawant, 2012). Perilaku pembelian konsumen dipengaruhi oleh faktor budaya, sosial, pribadi dan psikologis. Sebagian besar dari faktor-faktor ini tidak terkendali dan di luar tangan pemasar tetapi mereka harus mempertimbangkannya ketika mencoba untuk memahami perilaku konsumen yang kompleks (Vani, et al, 2010).

\section{Pengaruh Preferensi terhadap Keputusan Konsumen dan Keputusan Konsumen}

Tabel 2 pengujian hipotesis menunjukkan bahwa hipotesis ketiga pada penelitian ini diterima dan memiliki pengaruh yang positif. hasil ini menunjukkan bahwa preferensi konsumen akan mempengaruhi keputusan konsumen. keputusan yang akan diambil konsumen akan dipengaruhi oleh bagaimana preferensi konsumen yang dibentuk dari bagaimana konsumen tersebut memperoleh informasi, masukan, dan menyaring informasi tersebut yang akan dijabarkan dengan bagaiana sikap konsumen setelah memperoleh informasi dan kemunginan tindakan yang diambil oleh konsumen.

Hasil penelitian membuktikan bahwa, preferensi masyarakat berupa asal masukan, proses penyaringan informasi, pembentukan 
sikap, dan kemungkinan tindakan yang akan diambil akan mempengaruhi keputusan mereka dalam memilih perbankan. Preferensi masyarakat dalam perbankan syariah dipandang masih cukup rendah dibandingkan preferensi mereka terhadap perbankan konvensional. Hal ini disebabkan oleh kebanyakan masukan dan informasi yang mereka terima mengenai perbankan syariah masih dipandang minim dibandingkan perbankan konvensional. Sehingga mereka lebih mengenal perbankan konvensional, karena informasi yang mereka peroleh kemudian menjadi masukan dan akan membentuk sikap mereka dalam mengambil keputusan.

$$
\text { Umamaheswari (2014) dalam }
$$
penelitiannya yang berjudul a study on consumer preference toward textile retail outlets with special reference to selected textile outlets in Coimbatore City menjelaskan bagaimana keterkaitan preferensi konsumen mempengaruhi keputusan pembelian. Dari penelitian menyimpulkan pada preferensi pelanggan terhadap berbagai gerai ritel tekstil di kota Coimbatore ditemukan bahwa mayoritas responden yang membeli di showroom adalah laki-laki. Hal ini juga menemukan bahwa kecenderungan perempuan hanya akan untuk belanja telah berubah dan sekarang bahkan pria berbelanja lebih sering daripada wanita. Para responden terlihat untuk memberikan lebih banyak preferensi untuk koleksi saat memilih showroom. Mayoritas responden lebih memilih beli di Shree Devi dan karena pengecer lain juga dapat meningkatkan koleksi baru mereka. Dengan melihat penelitian tersebut maka dapat ditarik kesimpulan bahwa penelitian
Umamaheswari sejalan dengan penelitian ini dimana oreferensi akan mempengaruhi keputusan pembelian konsumen.

Preferensi yang mempertegas seseorang dalam memilih produk perbankan di Jember juga diperkuat oleh penelitian Decker dan Scholz (2009) yang telah memperkenalkan pendekatan baru untuk menentukan preferensi konsumen agregat. Demikian pula studi yang dilakukan Saeed dan Arshad (2008); Tariq, et al (2013)

\section{KESIMPULAN}

Penelitian ini membangun model preferensi konsumen dalam memilih perbankan syariah. Kesimpulan yang diperoleh dari penelitian ini menunjukkan bahwa preferensi masyarakat akan mempengaruhi pengambilan keputusan dalam memilih perbankan. Sedangkan preferensi masyarakat dalam memilih perbankan dipengaruhi oleh faktor aspek pribadi, apsek pemasaran, dan nilai sosial dan budaya yang ada di masyarakat. Dari ketiga aspek tersebut, aspek pemasaran memiliki posisi yang palig dominan dalam membentuk preferensi masyarakat dalam memilih perbankan. Hal ini dibuktikan dengan tingginya nilai koefisien pengaruh yang membentuk preferensi konsumen.

Implikasi dari penelitian ini yaitu perbankan syariah selain memperhatikan nilai sosial budaya, perbankan syariah juga perlu memperhatikan aspek pemasaran berupa produk, lokasi, dan promosi sehingga masyarakat mampu memperoleh informasi yang lebih baik dan mendpatkan pelayanan dan 
kemudahan dalam menjangkau perbankan syariah. Selain itu, faktor pribadi juga harus dipertimbangkan oleh perbankan syariah dalam menentukan kebijakan produk yang ditawarkan. Oleh karena itu esensi dari literasi dan preferensi masyarakat terhadap perbankan syariah dapat menjadi lebih baik dengan memperhatikan faktor-faktor yang dibahas dalam penelitian ini.

\section{DAFTAR PUSTAKA}

Abideen, saleem. 2012. Effective advertising and its influence on consumer buying behavior. European Journal of Business and Management. Vol 3, No. 3

Antonio, D. 1995. Bank Syariah: Suatu Pengenalan Umum. Tazkia Institute dan Bank Indonesia.

Assael, H. 1998. Customer Behaviour and Marketing Action. South Western Publishing. New York.

Best Roger J. 2010, Market based management, strategies for growing customer value and profitability, Pearson

Blackwell, R.D., P.W. Miniard, and Engel, 2001. Consumer behavior, ninth edition, harcourt

Boyd, walker, Larreche, 2000. Manajemen suatu pengantar strategis dengan orientasi global, Edisi 2 Jilid 1. Jakarta

Castro, 2006. Relationship marketing and consumer behaviour in fast-moving consumer goods. Thesis. Faculdade de Economia, Universidade Do Algarve.

Decker, Reinhold dan Scholz, Soren W. (2009). Preference Analysis and Default Optimization in Web-based Product Configuration Systems. Journal of Theoretical and Applied Electronic Commerce Research. Vol. 4, Issue 3, Desember.
De Silva, P. H. G. J., N. S. B. M. Atapattu, dan A. L. Sandika. 2010. A Study of the Socio-Cultural Parameters Associated with Meat Purchasing and Consumption Pattern: a Case of Southern Province, Sri Lanka. The Journal of Agricultural Science 5(2): 71-79.

Departemen Perbankan Syariah. 2015. Roadmap Perbankan Syariah Indonesia 2015-2019. Otoritas Jasa Keuangan

Engel, James F, Blackwell, Rogre D and Miniard, Paul W, 1994, Perilaku Konsumen, Jilid-1, Binaputra Aksara, Jakarta

Erol, C. dan R. El-Bdour. 1989. Attitudes, Behaviour and Patronage Factors of Bank Customers Toward Islamic Banks. International Journal of Bank Marketing 7(6): 31-37.

Furaiji, Fatimah dan Latuszynska, Malgorzata dan Wawrzyniak, Agata. 2012. An Empirical Study of the Factors influencing Consumer Behaviour in Electric Appliances Market. Contemporary Economics. Vol. 6, Issue 3

Gruber, Thorsten. Reppel, Alexander. Szmigin, Isabelle dan Voss, Roediger. 2008. Revealing the expectations and preferences of complaining customers by combining the leddering interviewing technique with the Kano model of customer satisfaction. Qualitative Market Research: An International Journal. Vol. 11, No. 4, pp: 1352-2752.

Huimin, Florence Hu dan Wei, Gao. 2013. The Impact of the Knowledge Sharing in Social Media on Consumer Behaviour. The Thirteen International Conference on Electronic Business, Taipei, December.

Howard, John A. And Sheth, Jagdish N. 1998. Consumer behavior and strategy. Irwin Mc Graw Hill. 
Jhingan, M.L, 2000. Ekonomi pembangunan dan perencanaan. PT. Raja Grafindo Persada. Jakarta

Lee, Cheng-Wen dan Liao, Chi-Shun. 2009. The Effects of Consumer Preferences and Perceptions of Chinese tea beverages on brand positioning strategies. British Food Journal. Vol. 111, No. 1, pp: 80-96.

Leo, C., R. Bennett, dan C. E. J. Hartel. 2005. Cross-cultural Differences in Consumer Decision-Making Style. Cross Cultural Management: An International Journal 12(3): 32-62.

Koklic, M. K. dan I. Vida. 2009. A Strategic Household Purchase: Consumer House Buying Behaviour. Managing Global Transitions 7(1): 75-96.

Kotler, Philip, 2002, Manajemen Pemasaran, Edisi Milenium, Jilid 3, Penerbit Prenhallindo: Jakarta.

Lawan, Lawan A dan Zanna, Ramat. 2013. Evaluation of Socio-Cultural Factors Influencing Consumer Buying Behaviour of Clothes in Borno State, Nigeria. International Journal of Basics and Applied Sciences. Insan Akademika Publications. Vol 01. No. 03, pp. 519-529

Leo, Cheryl dan Bennett, Rebekah dan Hartel, Charmine E.J. (2005). Cross-Cultural Differences in Consumer DecisionMaking Styles. Emerald Publishing. 12(3). Pp, 32-62.

Lovelock, C. And Wright, L. 2002. Principle of servives marketing management. Upper Saddler River, Prentice Hall

Macionis, John J. 1997. Sociology, 6th Edition, Prentice Hall

Mowen, J. C., Minor M., 1998, Consumer Behavior. 5th edition, Prentice Hall, New Jersey

Mutsikiwa, Munyaradzi dan Basera, Hutama Clay. (2012). The Influence of SocioCultural Variabels on Consumers'
Perception of Halal Food Products: A Case of Masvingo Urban, Zimbabwe. International Journal of Business and Management. Vol. 7, No. 20.

Peter, J. P. dan J. C. Olson. 2000. Perilaku Konsumen dan Strategi Pemasaran. Jilid 1. Erlangga. Jakarta.

Rajagopal. 2011. Consumer culture and purchase intentions toward fashion apparel in Mexico. Macmilan Publishers Ltd. Database Marketing \& Customer Strategy Management. Vol. $18,4,286-307$.

Rajasekhar, Sandhya dan Makesh, Deepa. 2013. Impact of advertising on brand preference of high involvement products. IRACST, Intenational Journal of Commerce, Business and Management. ISSN: 2319-2828. Vol. 2, No. 4.

Saeed, Aitzaz dan Arshad, Rehan. 2008. Corporate branding and customer's purchase preferences in mobile phone telecommunication. Halmstad University. School of Business and Engineering. International Marketing.

Sawant, Ms Roshni P. 2012. Impact of Advertising on Brand Awareness and Consumer Preference (With Special Reference to Men's Wear). IOSR Journal of Business and Management (IOSR-JBM) ISSN:22. Volume 5, Issue 6, pp 54-61

Silva, P.H.G.J. De dan Atapattu, N.S.B.M dan Sandika, A.L. 2010. A Study of the Socio-Cultural Parameters Associated With Meat Purchasing and Consumption Pattern: A Case of Southern Province, Sri Lanka. The Journal of Agricultural Science, Vol. 5, No. 2.

Schiffman. 2007. Consumer Behaviour. Seventh Edition. Prentice Hall International. New Jersey.

Sciffman, Leon, G dan Kanuk, Leislie Lazar. 2000. Consumer Behavior. Seventh Edition, Prentice Hall International. New Jersey 
Solomon. 2002. Consumer Behaviour: Buying, Having, and Being. Prentice Hall. New Jersey.

Tariq, Muhammad Irfan dan Nawaz, Muhammad Rafay dan Nawaz, Muhammad Musarrat dan Butt, Hashim Awais. 2013. Customer Perceptions about Branding and Purchase Intention: A Study of FMCF in an Emerging Market. Journal of Basic and Applied Scientific Research. ISSN. 2090-4304. 3(2), 340-347.

Tjiptono, Adisasono. 2008. Karakteristik sosiologi Konsumen. Jakarta. Elex Media Komputindo
Umamaheswari, R, Nagamuthu, 2014. The impact of marketing Mix on the Consumer experience in fast food Industry. International Journal of Research and Development, A Management Review. Vol 3, Issue 2.

Vani, $G$ dan Babu, M. Ganesh dan Panchanatham. 2010. Toothpaste Brands - A Study of consumer behavior in Bangalore City. Journal of Economics and Behavioral Studies. Vol. 1, No. 1, pp 27-39.

http://www.ey.com/Publication/vwLUAssets/E Y-world-islamic-bankingcompetitiveness-report-201415/\$FILE/EY-world-islamic-bankingcompetitiveness-report-2014-15.pd 